\title{
Hunger and the humanitarian frontier
}

\section{Anne O’Brien}

Within a few days of settlers' arrival in Eora country in 1788, disruptions to the ecological balance between population and food supply were set in train. The first conflicts were over fish and the officers soon observed that the local people were 'very hungry'. ${ }^{1}$ Over the next century and a half as settlement spread across the continent, so too did these disruptions. Their rate and extent was not everywhere the same. Different economic modes and different demographics varied their impacts, and bush food continued to be important. Indeed, recent research shows that in some contexts settlers embraced and depended on Indigenous foodways. ${ }^{2}$ But while such insights are important in variegating the larger story, disruption to food supplies was one of colonialism's irrefutable consequences. This knowledge has informed the writing of Indigenous historiography since the 1970s. Henry Reynolds' influential The Other Side of the Frontier (1981) saw the European invasion resulting in 'chronic insecurity' in relation to food, and much of his analysis of resistance proceeds from conflict over resources. ${ }^{3}$ A decade earlier, C. D. Rowley wrote that there was 'a kind of inevitability' in the progression from the 'destruction of native food supply, or of the incentives to hunt and gather it' to rationing. ${ }^{4}$

To draw out the significance of food is not to ignore the social and spiritual disruption that came from the land grab but to contribute to ways of understanding it. The 'history wars' raised questions about physical violence in the past but debate was stiflingly constricted to the extent of 'massacres'. ${ }^{5}$ Hunger was another form of physical violence, more difficult to determine,

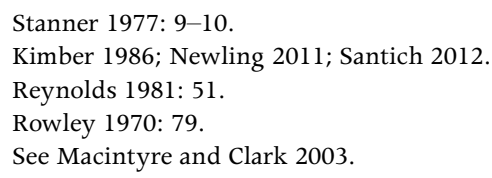


more deeply embedded, but one with a history of its own. Indeed Rowley's reference to the loss of 'incentives to hunt and gather' points to a second and related theme in the history of colonialism - the cluster of ideas surrounding settlers' fear that Indigenous people would become 'pauperised'. Deriving from centuries of exploitation and prejudice, the European myth of 'the lazy native' exacerbated fears that ready relief would destroy the will to work. Described by Shino Konishi as one of the most 'devastating and enduring myths about Indigenous people' this idea, too, has generated a considerable historiography. ${ }^{6}$

This article examines how the relationship between loss of food and fears of pauperisation were played out in central and northern Australia from the 1920s to the 1950s, a time and place when tightening tensions between the desire to include and old racist fears threw the contradictions in this relationship into sharp relief. A site of relatively late colonial occupation, central Australia was seen as the 'last frontier', a space where anthropologists, medical scientists and missionaries hoped that traditional life might continue unimpeded, but where the cattle industry was precarious, dependent on large tracts of land and Aboriginal labour. In the context of national politics, a decade of depression in the 1930s was followed in the 1940s by visions of 'a new social order' and, as Russell McGregor has argued, there was a shift in public attitudes that sought to include Aboriginal people as 'full participants in the life of the community'. ${ }^{7}$ Broadening the horizon to the British Empire, historian James Vernon argued that 'the hungry 1930s' were the final stage in the long 'ethical reorientation of hunger' that had started with the Irish famine and shifted hunger from the realm of moral fault. ${ }^{8}$

Vernon's survey offers a useful 'big picture' of British thought but the settler colonial context suggests we rethink the boundaries of its 'ethical reorientation'. As McGregor noted, the shift towards inclusion was always incomplete, impeded by a 'formidable array of prejudices and assumptions' ${ }^{9}$ This article focuses on some of the prejudices and assumptions underpinning the work of missionaries, protection societies, medical scientists and government officials all of whom were concerned in one way or another with the physical well-being of Indigenous peoples and who can thus be seen as falling under the broad mantle of 'humanitarianism'. Beginning with the food problems that dogged the mission established at Ernabella in north-west South Australia in 1937, it argues that old fears of the demoralising effects of relief were given new life by a new wave of post-war cultural awareness and anti-paternalism. These new impulses did not, however, see the end of older practices among missionaries

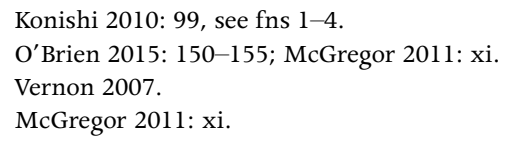


and government officials - practices of using food to control movement that in themselves fuelled representations of Indigenous dependency. Further, the reporting of poverty and poor health was informed by racist assumptions that excited particularly virulent fears of pauperism. Even as they reported the loss of subsistence - the term 'semi-starvation' was not uncommon - official reports slipped into the language of pauperism: people were half-starved on one page of a report, 'loafers' and 'spongers' on the next.

Focusing on the long relationship between humanitarianism and philanthropy helps explain these contradictions. If humanitarians are usually assumed to be those whose 'pre-eminent concern was with people's material conditions', that concern was entwined with a durable strain of moral reform that provided deep support for evaluations focused on personal deficiency. ${ }^{10}$ To understand the thought worlds of those who were active and influential in Indigenous policy, we need to draw on the long history of philanthropy, where humanitarianism had its origins.

\section{Ernabella's problems - Anangu problems}

Much has been written about Ernabella, most of it less critical than analyses of other missions. ${ }^{11}$ Established by the Adelaide medical practitioner and Presbyterian elder Charles Duguid as a buffer between the Anangu Pitjatjantjara-Yankantjatjara and the 'doggers' who had come to inhabit the area in the 1920s, it aspired to a range of culturally sensitive policies to assist people in the transition to modernity - there was no compulsion for 'the natives' to wear clothes, classes were conducted in Pitjatjantjara language, missionaries did not interfere with initiation ceremonies or marriage customs, nor insist that people stay on the mission. Indeed, unlike most missions Ernabella did not seek a permanent congregation so, unlike most missions, it did not use food to attract one. Historians Peggy Brock, Rani Kerin and David Trudinger have explored the problems that arose from Ernabella's food policies. ${ }^{12}$ I would like to build on their work by focusing on the ideological sources of that policy and contextualising the principles that informed it. At its heart was Duguid's conviction that supplying 'nothing but our kind of food' would 'wreck a fabric of life that has stood the test of centuries'. ${ }^{13}$

10 Laidlaw 2007: 138.

11 McGregor 2011: 105; Kerin 2011; Trudinger 2004; Hilliard 1968; Edwards 2012.

12 Brock 2007; Kerin 2011; Trudinger 2004.

13 Duguid 1939: 3-5. 
Anangu had indeed managed the resources of their lands for centuries. Though the area was semi-arid, Ernabella's rockhole gave it strategic importance. When in 1873 the explorer Ernest Giles came across it after crossing miles of waterless desert, its apparent permanence led him to wax eloquent about this 'delightful and fanciful region' and it came to be seen as a safe sanctuary on the edge of a vast western desert. ${ }^{14}$ To the Pitjatjantjara and other local peoples, it was a fertile and significant site. When interviewed in the early 1980s, the partArabana bushman Walter Smith recalled it as 'the best place ... Plenty of rabbits, wallabies and euros' ${ }^{15}$ Though plants and animals died out at times of drought, they re-established following good rains. Anangu were reasonably resistant to climatic fluctuations because they knew the country and they were able to move to places where food and water were accessible. ${ }^{16}$ An 'Anthropological expedition' conducted by Norman Tindale in the late 1930s found that the Pitjatjantjara turned to deep sand soaks and rock sheltered pools in dry periods, and they 'knew which springs had never failed them' ${ }^{17}$ Narratives of 'two-way food' run through Ernabella's oral testimony. In the late 1990s, Anangu whose parents were part of this mixed economy remembered the best sites for honey ant hunting and where they had set up 'sheep camps' near the wells they had sunk. ${ }^{18}$

But outbreaks of disease cast a shadow on Ernabella's first two decades. Epidemics were not unusual in Central Australia in the first half of the twentieth century as people who had previously been isolated were exposed to infection. ${ }^{19}$ But the outbreaks at Ernabella were particularly disturbing because medical care was fundamental to its origins. Duguid had conceived it as a 'medical mission'. In his travels north in 1934 and 1935, he had been appalled by the malnutrition and disease suffered by Aboriginal people in Alice Springs and disgusted to find venereal disease rampant among Aboriginal women and children in the Musgrave Ranges. But though the Presbyterian Board of Mission rejected his initial model that it be only a 'medical mission' - he had seen 'no need for a padre' - the physical health of the people remained one of its main purposes. In addition to treating the minor injuries and infections of those who camped near the mission, each year a medical patrol moved out into the Central Aboriginal Reserve. ${ }^{20}$

14 Gee 2003: 43; Hilliard 1968: 40.

15 Kimber 1986: 49.

16 Robinson et al. 2003: 22.

17 Tindale 1940: 151.

18 Cited in Young 2010: 98-99.

19 See Goodall 1994: 60-62.

20 Kerin 2011: chapter 1. 
If epidemics challenged Ernabella's very purpose, the possibility that they were exacerbated by its food policy was jarring indeed. And yet this was the finding of two inspectors sent by the South Australian Aborigines Protection Board during a flu epidemic in 1943, in which over 300 Anangu contracted influenza and eight died. In their report, Constance Cooke and Alice Johnston noted the 'fortitude, long hours and self-sacrifice' of the missionaries in caring for the sick, but they also wrote that some of the Aborigines were 'under-nourished', and that the food provided to both 'the pensioners' - the old, sick and young - and to the workers was neither adequate nor nutritious. ${ }^{21}$ They named 'underfeeding' as Ernabella's major problem. Their reports were devastating to Duguid and he rushed to blame the Superintendent Rev. Robert Love, despite having head-hunted him for Ernabella in 1940 as one of the most 'experienced, sensible and anthropologically minded' missionaries in Australia. Now Duguid believed rumours that there had been an 'appalling' and 'preventable' death rate among the Worowa at Kunmunya in Western Australia, Love's previous posting. As Duguid's biographer Rani Kerin argues, Duguid's extreme reaction was a symptom of his anxiety about Ernabella's future - its lease was coming up for renewal - and his inability to attach any blame to the mission itself. ${ }^{22}$

Following this, 'additional foods in greater variety' were provided at Ernabella, but in 1948 an epidemic of measles struck. ${ }^{23}$ Its mortality rates were much worse - between a quarter and a third of the approximately 300 Anangu at Ernabella died - and it killed hundreds more people from Alice Springs to Western Australia. ${ }^{24}$ Duguid flew to Ernabella with 'a plentiful supply of penicillin, sulphadiazine, and invalid foods' and stayed for a week until the worst effects were passed. ${ }^{25}$ In 1957, measles struck Ernabella once more - 106 people were infected, of whom 24 children and two adults died. Three sick children sent to the Adelaide hospital for treatment were all reported to be malnourished. Duguid visited the mission to find the diet totally inadequate. It fell below the nutrition levels recommended by the Commonwealth Government's Ration Scale for Feeding of Aborigines. ${ }^{26}$ Unsurprisingly, Duguid found this state of affairs 'most perturbing', given that 'all concerned' with the mission had hoped it 'would set an example to the rest'. ${ }^{27}$

How can we explain the problems over food that dogged Ernabella? Why did they persist and what is their significance? There were clearly practical difficulties in running a mission 1,400 kilometres from Adelaide. Infestations of weevils

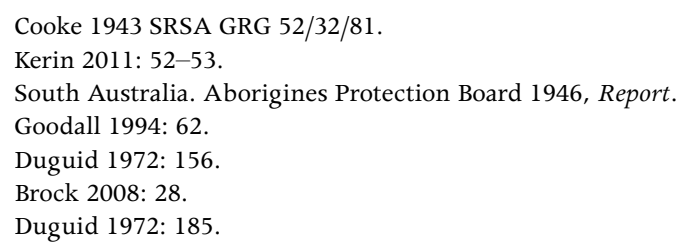


made it hard to keep food and during the war transport delays of supplies from Adelaide were common. ${ }^{28}$ Part of the explanation must also lie in the unpredictability of the climate and its effects on bush food. During the epidemic of 1943 Ernabella experienced a drought that lasted 19 months, the longest ever recorded since rainfall started to be measured in $1935 .{ }^{29}$ There was a drought in the first half of 1957, too, by which time cattle stations were encroaching on the lands. The presence of the mission itself created population densities that put pressure on bush tucker. Twenty years of hunting and foraging in the area around the mission had thinned out supplies of food, a point Duguid acknowledged in his autobiography. ${ }^{30}$ Part of the answer, then, would seem to lie in a misreading of the availability of bush tucker in 'real time', and in the context of unpredictable rainfall.

But why were Ernabella's missionaries so determined to read the environment that way? What deeper ideological assumptions were at work? If the missionaries sought to protect Anangu morally as well as physically, their moral concerns were not restricted to 'undesirables' like the doggers, but encompassed the demoralisation that came with 'paternalism'. In his autobiography, Duguid recalled visiting the reserves, missions and camps in South Australia as a newly appointed member of the Aborigines Protection Board in the early 1940s, and finding no attempts being made 'to fit the Aborigines to stand on their own legs'. Without regular work or responsibilities they were 'hand fed', so it was 'no wonder' they turned to alcohol when they could get it. ${ }^{31}$ Duguid was determined that Anangu would not succumb to the same fate. But, as was the case in most missions, there was frequently not enough work to meet the demand, a problem exacerbated in Ernabella's case by isolation. ${ }^{32}$ For Duguid and his supporters, 'pauperism' would be contained if Anangu remained hunters of food. And in this they could be encouraged if the food on the mission was less appealing than could be acquired elsewhere. Ernabella, then, operated on principles of 'less eligibility', the clarion call of the Poor Law reformers of the 1830s who insisted that conditions in the workhouse be less attractive than those outside in order to discourage 'pauperism'. 'No work, no food' was the policy - if not the practice - not just of Indigenous missions, but of all organisations that sought funding to deal with 'problem populations'; the Salvation Army was often commended by government for the work it extracted from the white unmarried mothers, ex-prisoners and children in its institutions. ${ }^{33}$

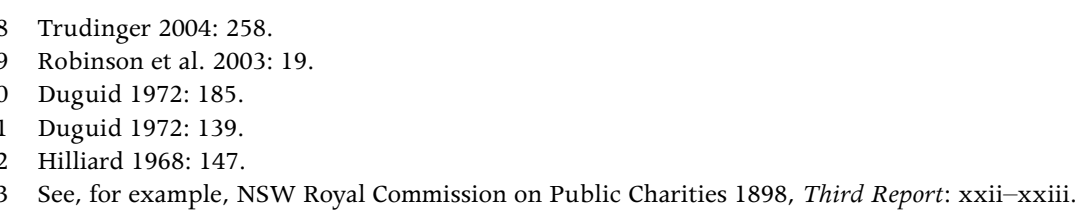


Ernabella's Presbyterian foundations may well have deepened its antipaternalism. Though only one branch of the radical Protestantism that Nancy Fraser and Linda Gordon have argued made the idea of dependency shameful from the eighteenth century, the Presbyterian Church stood out from the other major denominations in the early years of the Depression for its newspapers' support of a particularly robust individualism, coming close to admiring fascism in some of its articulations. ${ }^{34}$ But the mission's recoil from paternalism was also bolstered by respect for the qualities traditional life demanded. Duguid admired the fact that Aboriginal men were trained from boyhood to be 'courageous, self-controlled and self-reliant' and in his book Stone-Age Bushmen of Today (1936), Love spent many pages detailing the tenacity and skill involved in hunting - of women as well as men. In this, his book reflected and reinforced the growing fascination with and respect for what was seen as 'the authentic culture of primitive full bloods'.$^{35}$ But in the mission's daily operation, Love was so dedicated to saving Anangu from materialist contamination that he was reluctant to pay the 'doggers' among them more wages despite the urging of the Presbyterian Mission Board and he resisted introducing agriculture, arguing that the mission should 'let them continue to be nomadic' for hunting was intrinsic to 'tribal integrity' ${ }^{36}$ If Love's resistance to paternalism was particularly determined, he did not have it on his own. He retired in 1946 having lost, in the view of a missionary historian who knew him well, 'the tremendous drive and vitality that had characterised him'. ${ }^{37}$ But in the mid-1950s, Ernabella's annual reports were still boasting that 'as little relief as possible is issued and the menfolk, where not employed, must hunt for their natural food'. ${ }^{38}$ In her history of Ernabella published in 1968, the crafts teacher Winifred Hilliard was proud to declare that 'the Pitjantjatjara tribesman' was not 'dependent upon the white man's employment to live' ${ }^{39}$

How typical was Ernabella? What light do these incidents shed on broader processes? Despite the appeal of 'less eligibility', the 'no work no food' policy was not applied universally in relation to Indigenous people. Multiple strategies were employed to control their movement in the central desert and one of them involved using food. As a technology of power, food distribution stretched back to the time of Macquarie's Native Feasts, and over the next century food was

\footnotetext{
34 According to politician and Presbyterian elder Sir Thomas Henley, 'idleness and unemployment were crimes' and that 'the best cure for unemployment was for everybody to work harder and harder'. NSW Presbyterian, 23 May 1929; Rev. D. J. Flockhart, a NSW Moderator, declared in 1930 that he had 'no brief for Mussolini or his methods', but admired his leadership and challenged those worried about 'hard times ahead of us' not to be 'weaklings'. NSW Presbyterian, 30 January 1930. See O'Brien 2015: 125.

35 Duguid 1946: 23; Love 1936: 16; McGregor 2011: 29-27.

36 Trudinger 2004: 258-259; Kerin 2011: 52-56.

37 McKenzie 1969: 104.

38 Cited in Raftery 2006: 216.

39 Hilliard 1968: 154.
} 
used to appease, cajole and control movement with little or no attempt to exact a return. As the transcontinental railway was built across the Nullarbor and from Adelaide towards Darwin between 1909 and 1957, food was used to stop 'drift', as the movement of Aborigines towards white population centres was known. ${ }^{40}$ Seen as a threat to hygiene, morals, good order and the whiteness of the population, 'drift' impelled the United Aborigines Mission at Ooldea to provide cooked food, not just rations to the southern Pitjatjantjara in the 1930s and 1940s. ${ }^{41}$ Even Pastor Frederick Albrecht of Hermannsburg, who believed that 'a Christian cannot be a parasite', offered varied and attractive food - and he was critical of Ernabella's austerity. ${ }^{42}$ It is significant that things were different on some of the older missions, where the populations had been settled for decades. Without the need to manoeuvre behaviour, conditions were very poor. At Yarrabah, for example, which was grossly underfunded by the Queensland government despite having been used as an industrial school and reformatory since the early 1890s, the government medical officer, Raphael Cilento, reported in 1935 that the diet was 'entirely lacking in vitamins' and 'an actual menace to healthy development'. Three years later, the anthropologist Norman Tindale reported that rations were 'only enough to prevent starvation' ${ }^{43}$ But despite these different outcomes, the use of food in the long history of land grab compounded the ambivalence surrounding Aboriginal entitlement and hunger. ${ }^{44}$ In a circular and self-reinforcing paradox, using food to influence movement fostered images of Aborigines as dependent and contributed to the fears of pauperisation that perpetuated hunger by representing them as undeserving.

\section{'Malnutrition and other drawbacks'}

Before addressing the significance of these tropes we need to ask what is known of the extent of hunger experienced by Indigenous people in central and northern Australia? There is no unitary, all-encompassing narrative. Bush tucker remained an important source of food as well as a source of 'independence and cultural pride' to the people interviewed by Ann McGrath in her study of the cattle industry. ${ }^{45}$ Joe McGuiness recalled that since childhood he was 'conditioned to live off the land' and was 'quite used to lean times' ${ }^{46}$ Some autobiographies recall childhoods of plenty. Eileen Kampakuta Brown remembers travelling from the spinifex country, being 'very happy walking along' and of 'eating well of

\footnotetext{
Brady 1987: 36.

Cited in Brady 1987: 38-39.

Cited in Trudinger 2004: 265-267; Rowse 1998: chapter 5; Brock 2008: 27-28.

Cited in Loos 1991.

Nettlebeck and Foster 2012.

McGrath 1988: 173.

Cited in Broome 2002: 65.
} 
the game you catch on the way' ${ }^{47}$ Jessie Lennon remembers being 'at home with the sweet bush tucker' that accompanied her family's journeys. ${ }^{48}$ But it is not possible to know how many people were living on bush foods in the 1930s. ${ }^{49}$ Police estimated that by 1938 about half the Aborigines in the Northern Territory were supporting themselves on bush tucker, but as McGrath has argued, they could not check country inaccessible to horses, nor did they have knowledge of those 'bush' groups who avoided Europeans altogether. ${ }^{50}$

We do know that a slew of contemporary publications named hunger as endemic among certain groups. Two official inquiries held in response to a new mood of concern that emerged after the Forrest River massacre found that it triggered the 'outrages' that gave Australia its poor international reputation in the interwar years. In his 1929 report on 'The Aboriginal and Half-castes of Central Australia and North Australia', J. W. Bleakley wrote that the natives had been 'deprived of their natural means of subsistence by the usurpation of their tribal hunting grounds' and that it was their 'distress' that led to the killing that resulted in the Conistan massacre. In his view, Aboriginal women were forced into prostitution by 'semi-starvation', the 'camp dependents' of workers on cattle stations were in a state of 'semi-starvation', government rations were 'quite insufficient' and the majority of 'inmates' of the camps were 'in an emaciated condition' ${ }^{51}$ Four years later, Western Australia's Moseley Royal Commission noted that mortality rates from infectious disease - made more virulent by poor diet - were 'severe' in the south and 'very severe' in the Kimberleys. ${ }^{52}$ The government settlement at Moore River presented 'a woeful spectacle' and the food in 'the compound' where the children were housed left 'much room for improvement'. ${ }^{53}$

The inadequacy and insufficiency of food ran through the public pronouncements of urban humanitarian organisations. 'The ration scale was deplorable', wrote Rev. William Morely, Secretary of the Association for the Protection of Native Races, in his campaign to do something about the 'half-caste' home outside Alice Springs. ${ }^{54}$ Medical scientists and physical anthropologists were important sources of information on diet, as we have seen in relation to Yarrabah. One of the most outspoken anthropologists was the young William Stanner. For him 'the poverty of native nutrition' was a central feature of 'the brutal reality' of Aboriginal life. In a chapter published in London in 1938 - the first he chose to

47 Brown 2003: 1.

48 Lennon 2000: 96.

49 McGrath 1988: 173. In one of the first studies of Aboriginal diet in 1948, the nutritionist Margaret McArthur found the diet of the Yolgnu in Arnhem Land, where fish were plentiful, was 'well balanced' by international standards. McArthur et al. 2000.

50 McGrath 1988: 27.

51 Bleakley 1928: 32, 9, 10.

52 Western Australia. Royal Commission 1935: 10.

53 Western Australia. Royal Commission 1935: 12.

54 Association for the Protection of Native Races 1930, Annual Report: 5. 
include in his influential and career-defining White Man Got No Dreaming (1979) - he spent a considerable amount of text on food and nutrition, linking both directly to the dying of the race. He declared that 'the process of extinction still goes on' and connected this to the fact that most of the 'detribalised and semicivilised natives' were 'badly under-nourished' and living on 'what in many cases is a wretchedly inferior diet'. Rations had been intended to supplement traditional hunting but 'in so many outback areas' they were all the people received and they were 'a mockery of an adequate level of diet' - there was no meat, and in quantity it was enough to encourage people to stay at the ration depot but not enough for 'one square meal a day'. He was a lone voice calling for research that would find out 'the extent to which food deficiency is actually to blame for their low condition'..$^{55}$

These were powerful words but claims of 'starvation' were not unusual in the Depression - particularly when newspapers were looking for good copy - and historians have disputed the use of the term in relation to the white population. ${ }^{56}$ But these observations cannot be dismissed. Bleakley was a senior government official and he used the term 'semi-starvation' in what has been criticised as a 'bland' report. ${ }^{57}$ While it was clearly an attempt to get the attention of politicians who ranged from indifferent to hostile, Bleakley's words implied a threat to life. For Stanner, bad nourishment was the prelude to 'extinction'. His call for research and his references to food that was inferior as well as insufficient reflected the growth of the science of nutrition and the 'discovery' of malnutrition in the interwar period, a process in which South Asia and Africa provided the 'colonial laboratories' for British nutritionists. ${ }^{58}$ Certainly the term 'malnutrition' was used frequently in these years, particularly in relation to the young and the old. It appears in the National Library of Australia's newspaper index 'Trove' over 6,000 times in the 1930s, compared with less than half that many times in the 1920s. But whereas a range of government and private initiatives addressed the malnutrition of white people, there was a sense of inevitability about Indigenous malnutrition. When A. O. Neville, the Protector of Aborigines in Western Australia, told the Friendly Union of Soldiers' Wives in 1937 that only 7 per cent of 'cases' examined had diseases 'in spite of malnutrition and other drawbacks' he was declaring it a fact of life. ${ }^{59}$

Aboriginal activists in New South Wales and Victoria used both 'starvation' and 'malnutrition' frequently and sometimes interchangeably. In New South Wales, unemployment forced many people onto managed insanitary reserves where they

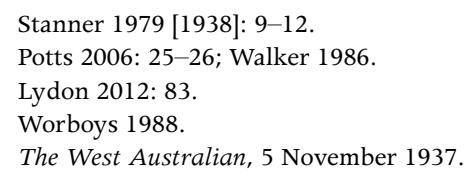


were given inadequate rations instead of the dole.$^{60}$ One of activist Pearl Gibbs' enduring memories of living with her mother at the La Perouse reserve during the Depression was seeing the dole being given to the white unemployed while Aborigines were given rations ${ }^{61}$ It is not surprising that the early 1930 s saw the emergence of a coalition of Indigenous activist groups fighting for the rights of Aboriginal people. ${ }^{62}$ During the 1937 Select Committee into the Aborigines Protection Board, William Ferguson, President of the Aborigines' Progressive Association in New South Wales, declared there was 'starvation of aborigines on all reserves'. Malnutrition caused through the supply of insufficient food was 'largely responsible' for the 'alarming' incidence of tuberculosis at Menindie and Bulgandramine mission stations and he called for the closure of both stations. ${ }^{63}$ For activists, 'starvation' may well have encompassed the authoritarianism and callousness of the Board and some of its station managers. ${ }^{64}$ In the memory of people who were removed to institutions, food was a 'central preoccupation' - not only for its insufficiency and awfulness, but because it was used as a punishment. ${ }^{65}$

Comparative funding of institutions support these claims. In 1905, when missions were registered as Industrial Homes for neglected children in Queensland they received an allowance of 2/6d per week per head compared with $7 /$ - per child paid to children in the State Children's department. ${ }^{66}$ Patricia Jacobs' biography of Western Australian Protector A. O. Neville shows the resistance offered to funding Aboriginal welfare by generations of politicians who were not interested in changing the system from which they benefited ${ }^{67}$ Accusations of pauperism are particularly disturbing when we consider that workers' wages were channelled into government coffers to help make up the shortfall in funding institutions. ${ }^{68}$

There was no effective regulation of the conditions outlined in the Bleakley and Mosely reports. Bleakley had recommended the introduction of wages but pastoralists lobbied to defeat any reform. ${ }^{69}$ Cattle workers were remunerated in food not wages and though Aboriginal workers expected employers to provide for kin, they were not legally compelled to do so. ${ }^{70}$ While in some ways these patterns replicated those in the south and east in the nineteenth

60 Goodall 1996: chapters 13 and 14.

61 Goodall 1983.

62 Maynard 2007.

63 Dubbo Liberal and Macquarie Advocate, 8 September 1938; Newcastle Morning Herald, 23 November 1937.

64 Wise 1985: 181.

65 Mellor and Haebich 2002: 201.

66 Haebich 2000: 178.

67 Jacobs 1990.

68 Kidd 1997.

69 Markus 1990: 52-53.

70 McGrath 1988: 123-124. 
century, the northern cattle industry was marginal in the interwar period and survived only because of its access to large areas of land and cheap Aboriginal labour. Indeed, it was so precarious that it could not absorb all the Aboriginal labour in the Northern Territory. ${ }^{71}$ This was the context in which 'bush bandits' hid out in rugged localities, spearing cattle for food and, on the coastal areas, in retaliation. ${ }^{72}$ And it was a context in which - despite knowledge of encroachment, loss of water-holes, drought and endemic unemployment government authorities, who had the monopoly on food, used 'bush tucker' as a weapon and a shield. After the terrible death rate that followed four years of drought between 1925 and 1929 - which resulted in the deaths of 85 per cent of Arrernte children at Hermannsburg mission - the NT Chief Protector Dr Cecil Cook blamed the missionaries for not sending out the workers to hunt for bush foods even as visiting scientists and anthropologists declared such food to be 'absolutely unobtainable'.$^{73}$

In the 1940s and 1950s, the increased activism of urban Indigenous organisations and the inclusive impulses of the 'new social order' saw attempts to improve the quality and availability of food for Indigenous people. In 1944, A. P. Elkin sent four of his anthropology students to north-western New South Wales to investigate the health and well-being of communities, and at the 1948 Conference of Commonwealth and State Aboriginal Welfare Authorities he argued for a 'complete medical and health survey' of dietary conditions amongst 'nomadic aborigines' and those on reserves and stations with a view to 'correcting dietary deficiencies'. But not a lot came from these initiatives. A 1944 survey by Ronald and Catherine Berndt of conditions on Wave Hill Station that recommended decent medical services and adequate diet was never published. ${ }^{74}$ A new Food Standards Committee of the National Health and Medical Research Council was established in 1953, but its focus was on the fitness and productivity of white Australia. A massive campaign was undertaken from 1948 to 1976 to eradicate tuberculosis in Australia but, despite their vast over-representation among sufferers, no effort was made to include Aborigines. ${ }^{75}$ In 1951, a survey by Winifred Wilson of the Australian Institute of Anatomy into the diet of Aboriginal people in the Northern Territory found that 84 per cent of the 38 groups surveyed were between 60 and 140 per cent below the recommended levels of Vitamin C and Vitamin A. ${ }^{76}$ In 1957, the Commonwealth Department of Health set down a Ration Scale for Feeding of Aborigines but it was not made mandatory. That year there was another 'discovery' of hunger among the

\footnotetext{
Markus 1990: 52-53.

McGrath 1988: 173, 16-19.

Cited in Brock 2008: 26.

Cited in Gray 2014: 15, 18.

Farrer 2005: 139; Stylianou 2009.

Cited in Brock 2008: 28.
} 
Yarnangu living in and around the Warburton Range. In the midst of debate over atomic testing and increased mining, the Western Australian politician William Grayndler forced an inquiry and, with the Yorta Yorta activist Pastor Doug Nicholls, made a film that brought the urgent need for reform to public attention. $^{77}$

The perspective of families and survivors of the Warburton Range controversy challenge a monochrome interpretation of these events, warning of the potential confusion over 'norms of well-being' associated with remote Australia and the dangers of generalising over such a vast space. ${ }^{78}$ They insist that their circumstances were localised and provoked by drought and that those living in the bush 'had to be like that'. It was a given that nomadic and semi-nomadic people 'lived with a high level of what most non-desert dwellers would consider discomfort and poverty' but their lifestyle was viable and desirable and it needed to be lived 'close to the edge'. Anthropologists Pamela McGrath and David Brooks have argued Yarnangu do not see themselves 'tossed about by colonial forces' but as having determined or actively responded to events. ${ }^{79}$

Focusing on the changes brought by colonisation and how settlers (mis)managed them does not discount the choices that were made, nor undermine the strength and adaptability of Yarnangu. It throws them into relief. At Ernabella, the Pitjatjantjara-Yankantjatjara not only survived as peoples, they developed a flourishing arts and crafts industry. Peggy Brock has argued that like many missions and settlements, Ernabella offered protection from violence, shelter and cultural and social interaction. ${ }^{80}$ Many people have positive memories of Ernabella - particularly of Duguid and of teachers Winifred Hilliard and Nancy Shepherd. In a 1988 oral history collection, Nganjinta said of Duguid, 'He really loved us and cared about us and was one of us' ${ }^{81}$ Heather Goodall points out that there are 'no easily identifiable villains' in the history of disease; but the deep structures of thought that underpinned 'everyday culture' permitted needless suffering and death. ${ }^{82}$

\footnotetext{
77 McGrath and Brooks 2010.

78 Rowse 1998: 214.

79 McGrath and Brooks 2010: 132.

80 Brock 2008: 29.

81 Mattingly and Hampton 1988: 255.

82 Goodall 1994: 61; Lydon 2012: 26.
} 


\section{Pauperism and racism}

What do we know of those deep structures of thought? Why did it not prompt more action to address these conditions? On one level the answer lies in the political insignificance of a small minority. After more than a decade's advocacy, it seemed clear to William Morely, Secretary of the Association for the Protection of Native Races, that governments were moved to action only 'by anticipation of votes which make or unmake them' ${ }^{83}$ Morley also considered the churches 'strangely silent', though some worked behind the scenes to stop grazing licences being issued and others engaged in terse internal correspondence with government officials over the inadequate funding of missions. ${ }^{84}$ But churchmen who had to negotiate such funding rarely raised their voices publicly, and if they did it was usually in muted and general terms, particularly in rural areas where clergy's dependence on their wealthy congregations made them chary of getting land-owners and pastoralists offside. ${ }^{85}$ Emergencies evoked a response. After visiting scientists correctly diagnosed scurvy at drought-stricken Hermannsburg in the late 1920s, the mission launched a national appeal and various organisations and individuals rallied to send supplies, including a 'Farmer's son' who wrote to Adelaide's Advertiser to organise the transportation of dried fruit and vegetables. A few years later, Melbourne artist Violet Teague and her sister Una raised more than $£ 1,800$ to construct an eight-kilometre water supply pipeline from Koperilya Springs to Hermannsburg. ${ }^{86}$

But why was endemic hunger allowed to persist? Writers now and at the time have isolated 'indifference' as the defining politics of this period. In 1938, Stanner noted 'a few vestigial regrets' amid 'a mass of solid indifference'; historian Russell McGregor called his recent history of mid-twentieth-century policy Indifferent Inclusion. ${ }^{87}$ But as a form of politics, indifference invites scrutiny. It was certainly a recurring complaint of advocates, most of whom saw government indifference as culpable. Rev. Thomas Webb of the Methodist Mission charged the government with 'criminal indifference' in 1937. Speaking in London the same year, Charles Duguid claimed neglect and indifference so great that it constituted evidence that 'the Australian Government would like to see the aborigines die out' ${ }^{88}$ Others cast the blame more widely. The anatomist

\footnotetext{
83 Association for the Protection of Native Races, 1937-8, Annual Report: 3.

84 Rev. Albrecht at Hermannsburg long argued that 'natives and cattle will never go together'; he recalled telling a newcomer pastoralist that he would 'declare war on him' and shortly after the government cancelled grazing licences in the Haasts Bluff area and made it a permanent reserve. Leske 1977: 54; Kidd 1997: 66.

85 Williams 2014.

86 Anderson 2014; Hansen 2008.

87 Stanner 1979 [1938]: 2.

88 Daily Advertiser, 25 August 1937; The West Australian, 6 December 1937.
} 
and anthropologist Frederick Wood Jones blamed Australia 'as a nation' for being like a crook who repeatedly acknowledged that he owed a debt without any intention of repaying it..$^{89}$

But if most white Australians seemed indifferent, they were not passive onlookers. They were implicated in fundamental ways. Most would have accepted that industries benefiting from Indigenous land and labour should not have their profits jeopardised. Most would have agreed that the hunger of white people in the Depression made intolerable any hint of natives being 'carried' - and church newspapers made sure that their reports of missions dispelled any such fear. ${ }^{90}$ The anthropologist and advocate Donald Thomson extends our understandings of the nature of this implication. He discerned forms of engagement open to constructive persuasion but rooted in assumption. Writing in 1938, he declared he was 'quite sure' there was 'a public conscience in this matter' but 'the man in the street', who had no 'technical knowledge of the question', was left 'unsatisfied' and 'a little confused' ${ }^{91}$ Further, most of those who contributed to discussion had 'ready-made solutions' that they were 'determined to force' upon the Aborigine. ${ }^{92}$ His allusion to the firm opinions of interested parties suggests the pervasiveness of assumptions where, at worst, racism fed fears of pauperism that implied Aborigines were undeserving of better.

Even as they supplied evidence of hunger, many reports were couched in the language of pauperism. Despite his many references to the denuded landscape, despite knowing there was not enough work for all Aborigines in the Northern Territory, Bleakley's report was laced with complaints about 'loafers'. In contiguous sentences he noted that drought caused 'serious diminution of the food supplies' but this resulted in the 'desert blacks' drifting to the outstation wells and 'sponging upon the native well-attendants'. 'The tribal practice of sharing food', was an inducement to 'lazy ones to loaf around in the camp in a half-starved state instead of going farther afield and hunting their food in the bush'. And despite his observation that 'camp dependents' were 'in a state of semi-starvation' he did not think the government should provide for them unless 'disproportionate numbers of indigents justified it'. ${ }^{93}$ The Moseley Commission also combined critique with 'the lazy native' trope. Moseley was particularly critical of missions for encouraging 'the element of laziness, which is inherent

\footnotetext{
89 Wood Jones 1926: 497-498.

90 For example, the NSW Presbyterian declared unequivocally that 'aged, sick and infirm' Aborigines were 'given a sanctuary' on their missions but 'able-bodied adults' were not: 'The charge that missions make the blacks idle and encourage them to become beggars is not true of the missions of the Presbyterian Church.' NSW Presbyterian, 26 May 1927.

91 Thomson 1938.

92 Thomson 1938.

93 Bleakley 1928: 33, 10.
} 
in him' ${ }^{94} \mathrm{He}$ found that on most missions the native 'gets his food for nothing' and he, too, recommended bush food as a solution at the same time as being aware of how uncertain it was. The natives should be 'sent to the bush to get their own food' if there was not enough work on the mission; on the next page, he notes that many 'come from the bush because they cannot feed themselves' ${ }^{95}$ There were deeper anxieties than those concerning laziness. Running through official discourse was a fear of native 'appetite'; 'hunger for white man's food' carried an element of danger associated with long deprivation. Bleakley thought cattle spearers 'hungered for the beef to which they had become accustomed' and he worried they would 'cultivate an appetite for the white man's luxuries' ${ }^{96}$ At the 1937 Conference of Commonwealth and State Aboriginal Authorities, J. A. Carrodus, the Secretary of the Department of the Interior, argued in favour of corporal punishment instead of imprisoning Aboriginal offenders because goal would give them 'a taste of the white man's food'.$^{97}$

In their efforts to penetrate popular indifference, humanitarian organisations ran the risk of fanning fears of Aboriginal people as sources of contagion, representing them as threat as well as victim and eroding perceptions of their deservedness. ${ }^{98}$ Newspaper reports of medical opinion demonised as they exposed: all the children on Cowal Creek station in Queensland 'had rotten teeth and swollen festered gums', clear evidence of scurvy according to Archibald Watson, Professor of Anatomy at the University of Adelaide, and he recommended that Cowal Creek be 'wiped out as a pest hole'. ${ }^{99}$ Some reports of 'the problems of malnutrition' among Aboriginal children were more direct, blaming their parents for the 'neglect of mission facilities'. ${ }^{100}$ Some thought 'the native system of government' carried within itself 'the seeds of its own decay'. To Rev. John Sexton of South Australia's Aborigines' Friends' Association, the 'inadequacy of the Stone Age system to safeguard the native race' was a factor in population decline. ${ }^{101}$ The anthropologists Catherine and Ronald Berndt thought some humanitarians believed that Aborigines could not 'adapt themselves to white culture' and that the 'kindest solution' was 'to remain passive and await the extinction of the aborigines as a race'. ${ }^{102}$ It was not far from this deep blame to a form of genocide by neglect. Duguid was unusual in publicly accusing the government of wanting to see their demise, but he was not alone in holding such views. In reflecting on the health problems caused

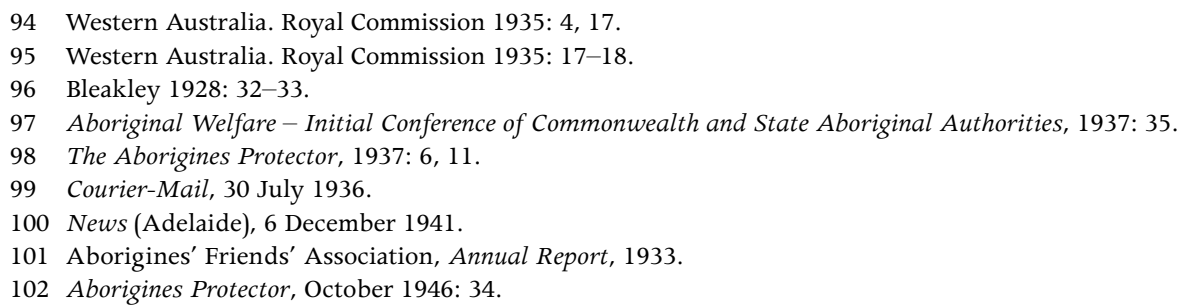


by the rations at Cummeragunga in 1938, the local doctor observed to Norman Tindale that 'the government may tacitly wish these hybrids to die out - at least they are doing a good job to help them' ${ }^{103}$ Indeed, the 'hybrids' were of great concern in this period because they were not dying out - in the words of Rev. Morely, 'the half-caste problem' was 'a menace to the whole of Australia'. ${ }^{104}$

\section{Historicising humanitarianism}

How can the historical relationship between philanthropy and humanitarianism help us understand the prejudices and assumptions that permitted so much hunger, ill-health and premature death?

There is a rich historiography of Indigenous humanitarianism in Australia, stretching back to Edmund J. B. Foxcroft's Australian Native Policy (1941). The humanitarian influence was developed in the colonial and state histories of race relations of the 1970s and 1980s, in the histories of interwar feminists, in the synoptic accounts of C. D. Rowley, Henry Reynolds and Bain Attwood and by the 'new imperial history' which emerged in the 1990s to trace the flow of humanitarian people and ideas across various sites of the nineteenth-century empire. ${ }^{105}$ More recently, global histories of humanitarianism have emerged. In 2009, as part of a series on 'global institutions', Routledge published a short history, Shaping the Humanitarian World by Peter Walker and Daniel Maxwell. Two substantial works were published in 2011: Humanitarian Intervention: A History, a collection edited by Brendan Simms and D. J. B. Trim that extends to the sixteenth century; and Michael Barnett's Empire of Humanity: A History of Humanitarianism.

Of these, Barnett's Empire of Humanity: A History of Humanitarianism has had most impact. The work of a political scientist, its scope and argument has been critiqued by some historians, but it has been widely welcomed as the most substantial long-range history of humanitarianism to date. ${ }^{106}$ Indeed, as Rob Skinner and Alan Lester have argued, it is the first 'serious and comprehensive' attempt to track the various strands of modern humanitarianism. ${ }^{107}$ Barnett posits two defining strands in humanitarianism's history - one he describes as 'alchemical', by which he means it sought to effect change that would remove the causes of suffering; the second he identifies as relief, or providing

103 Cited in Davis 2009: 112.

104 Association for the Protection of Native Races, Annual Report, 1938.

105 Foxcroft 1941; Biskup 1973; Reece 1974; Loos 1982; Markus 1990; Lake 1999; Paisley 2000; Holland 2001;

Rowley 1970; Reynolds 1998; Attwood 2003; Elbourne 2002; Lester 2009; Laidlaw 2002.

106 See Everill 2011.

107 Skinner and Lester 2012: 730. 
emergency aid in times of crisis. ${ }^{108}$ He looks to the origins of the alchemical strand in the late eighteenth-century anti-slavery movement but also situates it in contemporary shifts in understandings of charity and the emergence of the movement for moral reform, which sought to alter humankind as well as human society. However, the book does little to draw out the different manifestations of attempts to reform the person from those that sought to reform the polity. Further, given that most of the book is dedicated to the period after the Second World War, it does little to trace the continuing implications of moral reform over time.

I would argue that to understand the long history of humanitarianism more fully we need to situate its origins more centrally in the history of its older near relative - philanthropy. Doing so necessitates delineating the gaze of moral reform from that of social reform, even while recognising that they were closely linked. It is particularly important to acknowledge that at the end of the eighteenth century - the seminal moment in the gestation of modern humanitarianism - moral reform was in the ascendant, and that its concerns were not with alleviating physical suffering. The evangelicals who wanted to stop the suffering of the distant 'other' envisaged new ways of dealing with local suffering, as the foundation of the Society for Improving the Condition and Increasing the Comforts of the poor in 1795 - mid-point in the 'years of starvation' - attests. ${ }^{109}$ Providing personal and domestic counsel but not relief, it is testament to the strength of the new wave of 'culturally evolving assumptions about the responsibility of individuals for their own actions'. ${ }^{110}$ If empathy and compassion were at the core of modern humanitarianism, the ultimate act of compassion at the end of the eighteenth century was seen as enhancing the individual's opportunity for personal transformation.

I have argued elsewhere that though the term 'humanitarianism' came into increasing use following the first Geneva Convention of 1863, the older term 'philanthropy' did not disappear. Only after the Second World War with the rise of professional social work did the term 'philanthropy' go out of vogue and a new modern lexicon of 'help' emerge. But while the new language reflected new problems, new knowledge, and gave rise to new forms of assistance, these often belied underlying continuities - 'case work' was arguably moral reform in professional guise, 'community work' hoped to reform individuals by encouraging collective action. And despite shifts in form and approach, the gaze of moral reform remained directed towards the person. ${ }^{111}$

\footnotetext{
108 Barnett 2011: 10.

109 Owen 1964; Hilton 1988; Thorne 1997; Roberts 2004.

110 Cited in Barnett 2011: 52.

111 See O'Brien 2015.
} 
In the Australian colonies, the continuing interactions between moral reform, social reform and relief were played out in relation to settlers and Indigenous peoples, sharpened by the dream of 'independence'. ${ }^{112}$ In northern and central Australia in the first half of the twentieth century, Indigenous people who challenged the expectations of moral reform reduced their deservedness for relief and their right to a reformed social polity. Public attitudes towards Indigenous people did begin to shift in the mid-twentieth century, but the cluster of ideas surrounding settler aspirations to independence provided a backdrop to 'indifference', fortifying racist judgement. They help explain why the 'ethical reorientation of hunger' bypassed Indigenous people in Australia and why Australia's health disparities continue to be greater than those of any other settler society. ${ }^{113}$

\section{References}

\section{Archival source}

Cooke, Constance Ternent 1943, 'Impressions of a visit to Ernabella Mission', SRSA GRG 52/32/81, State Records of South Australia.

\section{Newspapers and periodicals}

The Aborigines Protector

Courier-Mail

Daily Advertiser

Dubbo Liberal and Macquarie Advocate

Newcastle Morning Herald

News (Adelaide)

NSW Presbyterian

The West Australian

112 See O'Brien 2015.

113 Anderson 2007: 150. 


\section{Government publications}

Aboriginal Welfare - Initial Conference of Commonwealth and State Aboriginal Authorities, held at Canberra, 21st to 23rd April, 1937, L. F. Johnston, Government Printer, Canberra.

Bleakley, John W. 1928, The Aboriginals and Half-castes of Central Australia and North Australia: Report, Commonwealth of Australia, Melbourne.

New South Wales. Royal Commission on Public Charities 1898, Third Report.

South Australia. Aborigines Protection Board 1946, Report of the Aborigines Protection Board for the year ended 30th June, 1946, Govt Printer, Adelaide.

Western Australia. Royal Commission 1935, Report of the Royal Commissioner appointed to Investigate, Report, and Advice upon matters in relation to the Condition and Treatment of Aborigines, Fred. Wm. Simpson, Perth.

\section{Non-government publications}

Aborigines' Friends' Association 1938, Annual Report, The Association, Adelaide.

Association for the Protection of Native Races 1930-38, Annual Reports, The Association, Sydney.

Duguid, Charles 1939, Ernabella: The Medical Patrol, 1939, Presbyterian Board of Missions, Melbourne.

-1946, The Aborigines of Australia: Broadcasts and an Address, Australian Broadcasting Commission, Adelaide.

—1972, Doctor Goes Walkabout, Rigby, Adelaide.

Stanner, W. E. H. 1979 [1938], 'The Aborigines', in White Man Got No Dreaming, Australian National University Press, Canberra.

Thomson, Donald F. 1938, 'A dying race: plight of the Aborigines', The West Australian, 7 May 1938: 5.

Tindale, Norman B. 1940, 'Results of the Harvard-Adelaide Universities Anthropological expedition 1938-9: Distribution of Australian Aboriginal tribes: A field survey', Transactions of the Royal Society of South Australia 64(1): 140-231.

Wood Jones, Frederic 1926, 'The claims of the Australian Aborigines', Reports of the Australasian Association of the Advancement of Science 18: 497-519. 


\section{Secondary sources}

Anderson, Warwick 2007, 'The colonial medicine of settler states: Comparing histories of Indigenous health', Health and History 9(2): 144-154.

-2014, 'Hermannsburg, 1929: Turning Aboriginal "primitives" into modern psychological subjects', Journal of the History of the Behavioral Sciences 50(2): 122-147.

Attwood, Bain 2003, Rights for Aborigines, Allen \& Unwin, St Leonards, NSW.

Barnett, Michael 2011, Empire of Humanity: A History of Humanitarianism, Cornell University Press, Ithaca, NY.

Biskup, Peter 1973, Not Slaves, Not Citizens: The Aboriginal Problem in Western Australia, 1898-1954, University of Queensland Press, St Lucia.

Brady, M. 1987, 'Leaving the Spinifex: the impact of rations, missions and the atomic tests on the southern Pitjantjatjara', Records of the South Australian Museum 20: 35-45.

Brock, Peggy 2007, 'Nakedness and clothing in early encounters between Aboriginal people of central Australia, missionaries and anthropologists', Journal of Colonialism and Colonial History 8(1), at: muse-jhu-edu. wwwproxy0.library.unsw.edu.au/journals/journal_of_colonialism_and_ colonial_history/v008/8.1brock.html, accessed 12 October 2015.

2008, 'Two-way food: bush tucker and whitefella's food', Journal of Australian Studies 32(1): 19-32.

Broome, Richard 2002, "No one thinks of us": The Framlingham Aboriginal community in the Great Depression', in Through Depression and War: The United States and Australia, Peter Bastien and Roger Bell (eds), AustralianAmerican Fulbright Association, Sydney: 62-81.

Brown, Eileen Kampakuta 2003, An Anangu-Aboriginal Love Story: My Young Life, Nyiri Publications, Murray Bridge, SA.

Davis, Fiona 2009, 'Calculating colour: Whiteness, anthropological research and the Cummeragunga Aboriginal Reserve, May and June 1938', in Creating White Australia, Jane Carey and Claire McLisky (eds), Sydney University Press, Sydney.

Edwards, Bill 2012, Mission in the Musgraves: Ernabella Mission 1937-73, a Place of Relationships, Uniting Church Historical Society, Adelaide. 
Elbourne, Elizabeth 2002, Blood Ground: Colonialism, Missions and the Contest for Christianity in the Cape Colony and Britain 1799-1853, McGill-Queens University Press, Montreal.

Everill, Bronwyn 2011, 'Review of Humanitarianism and Humanitarian Intervention, (review no. 1141)', www.history.ac.uk/reviews/review/1141, accessed 15 July 2015.

Farrer, Keith 2005, To Feed a Nation: A History of Australian Food Science and Technology, CSIRO Publishing, Melbourne.

Foxcroft, Edmund JB 1941, Australian Native Policy: Its history, especially in Victoria, Melbourne University Press, Melbourne.

Gee, P. 2003, 'The European history of the Anangu Pitjantjatjara Lands' in A Biological Survey of the Anangu Pitjatjantjara Lands of South Australia, 1991-2001, AC Robinson, PB Copley, PD Canty, LM Baker and BJ Nesbitt (eds), Department for Environment and Heritage, South Australia, Adelaide.

Goodall, Heather 1983, 'Pearl Gibbs: Some memories', Aboriginal History 7(1): 20-22.

1994, 'Colonialism and catastrophe: Contested memories of nuclear testing and measles epidemics at Ernabella', in Memory and History in TwentiethCentury Australia, Kate Darian-Smith and Paula Hamilton (eds), Oxford University Press, Melbourne.

1996, Invasion to Embassy: Land in Aboriginal Politics in New South Wales, 1770-1972, Allen \& Unwin, Sydney.

Gray, Geoffrey 2014, "We know the Aborigines are dying out": Aboriginal people and the quest to ensure their survival, Wave Hill Station, 1944', Health and History 16(1): 1-24.

Haebich, Anna 2000, Broken Circles: Fragmenting Indigenous Families 18002000, Fremantle Arts Centre Press, Fremantle, WA.

Hansen, Christine 2008, 'Two way flow: the Koperilya springs pipeline boomerang', National Museum of Australia, Collection Symposium 2008, Showcases 1, www.nma.gov.au/audio/transcripts/collections/NMA_ showcasesI_20080530.html, accessed 20 September 2014.

Hilliard, Winifred 1968, The People In Between: The Pitjantjatjara People of Ernabella, Hodder and Stoughton, London.

Hilton, Boyd 1988, The Age of Atonement: The Influence of Evangelicalism on Social and Economic Thought, 1785-1865, Oxford University Press, Oxford. 
Holland, Alison 2001, 'Wives and mothers like ourselves: Exploring white women's intervention in the politics of race, 1920s-1940s', Australian Historical Studies 32(117): 292-310.

Jacobs, Pat 1990, Mister Neville: A Biography, Fremantle Arts Centre Press, Fremantle, WA.

Kerin, Rani 2011, Doctor Do-Good: Charles Duguid and Aboriginal Advancement 1930s-1970s, Australian Scholarly Publishing, Melbourne.

Kidd, Rosalind 1997, The Way We Civilise: Aboriginal Affairs - the Untold Story, University of Queensland Press, St Lucia.

Kimber, R. G. 1986, Man from Arltunga: Walter Smith Australian Bushman, Hesperian Press, Victoria Park, WA.

Konishi, Shino 2010, 'Idle men: The eighteenth-century roots of the Indigenous indolence myth', in Passionate Histories: Memory and Indigenous Histories, Aboriginal History Monographs no. 23, Ann Curthoys, Frances Peters-Little and John Docker (eds), ANU E Press, Canberra: 99-122.

Laidlaw, Zoe 2002, 'Integrating metropolitan, colonial and imperial histories: The Aborigines Select Committee of 1835-37', in Writing Colonial History: Comparative Perspectives, Julie Evans and Tracey Banivanua-Mar (eds), University of Melbourne, Carlton.

2007, 'Heathens, slaves and Aborigines: Thomas Hodgkin's critique of missions and anti-slavery', History Workshop Journal 64: 133-161.

Lake, Marilyn 1999, Getting Equal: The History of Australian Feminism, Allen \& Unwin, Sydney.

Lennon, Jessie 2000, I'm the One that Know this Country, Aboriginal Studies Press, Canberra.

Leske, Everard (ed.) 1977, Hermannsburg: A Vision and a Mission, Lutheran Publishing House, Adelaide.

Lester, Alan 2009, Imperial Networks: Creating Identities in Nineteenth-Century South Africa and Britain, Routledge, London.

Loos, Noel 1982, Invasion and Resistance: Aboriginal-European Relations on the North Queensland Frontier, 1861-1897, The Australian National University Press, Canberra.

-1991, 'From church to state: The Queensland government take-over of Anglican missions in North Queensland', Aboriginal History 15: 73-85. 
Love, R. J. B. 1936, Stone-Age Bushmen of Today: Life and Adventure among a Tribe of Savages in North-Western Australia, Blackie and Son, London.

Lydon, Jane 2012, A Flash of Recognition: Photography and the Emergence of Indigenous Rights, NewSouth, Sydney.

McArthur, Margaret, Frederick McCarthy and Ray Specht 2000, 'Nutrition studies (1948) of nomadic Aborigines in Arnhem Land, northern Australia', Asia Pacific Journal of Clinical Nutrition 9(3): 215-223.

McGrath, Ann 1988, Born in the Cattle: Aborigines in Cattle Country, Allen \& Unwin, Sydney.

McGrath, Pamela Faye and David Brooks 2010, 'Their Darkest Hour: The films and photographs of William Grayden and the history of the "Warburton Range Controversy" of 1957', Aboriginal History 34: 115-141.

McGregor, Russell 2011, Indifferent Inclusion: Aboriginal People and the Australian Nation, Aboriginal Studies Press, Canberra.

Macintyre, Stuart and Anna Clark 2003, The History Wars, Melbourne University Press, Melbourne.

McKenzie, Maisie 1969, The Road to Mowanjum, Angus and Robertson, Sydney.

Markus, Andrew 1990, Governing Savages, Allen \& Unwin, Sydney.

Mattingly, Christobel and Ken Hampton 1988, Survival in Our Own Land: 'Aboriginal' Experiences in 'South Australia' since 1836, Wakefield Press, Adelaide.

Maynard, John 2007, Fight for Liberty and Freedom: The Origins of Australian Indigenous Activism, Aboriginal Studies Press, Canberra.

Mellor, Donna and Anna Haebich 2002, Many Voices: Reflections on Experiences of Indigenous Child Separation, National Library of Australia, Canberra.

Nettlebeck, Amanda and Rob Foster 2012, 'Food and governance on the settler frontiers of colonial Australia and Canada', Aboriginal History 36: 21-41.

Newling, Jacqui 2011, 'Dining with strangeness: European foodways on the Eora frontier', Journal of Australian Colonial History 13: 27-48.

O'Brien, Anne 2011, 'Humanitarianism and reparation', Journal of Colonialism and Colonial History 12(2). dx.doi.org/10.1353/cch.2011.0016.

2015, Philanthropy and Settler Colonialism, Palgrave Macmillan, Houndmills, Basingstoke. 
Owen, David 1964, English Philanthropy, 1660-1960, Harvard University Press, Cambridge, MA.

Paisley, Fiona 2000, Loving Protection?: Australian Feminism and Aboriginal Women's Rights 1919-39, Melbourne University Press, Melbourne.

Potts, David 2006, The Myth of the Great Depression, Scribe, Melbourne.

Raftery, Judith 2006, Not Part of the Public: Non-Indigenous Policies and Practices and the Health of Indigenous South Australians 1836-1973, Wakefield Press, Adelaide.

Reece, R. H. W. 1974, Aborigines and Colonists: Aborigines and Colonial Society in the 1830s and 1840s, Sydney University Press, Sydney.

Reynolds, Henry 1981, The Other Side of the Frontier: Aboriginal Resistance to the European Invasion of Australia, Penguin, Ringwood, Victoria.

1998, This Whispering in Our Hearts, Allen \& Unwin, Sydney.

Roberts, M. J. D. 2004, Making English Morals: Voluntary Associations and Moral Reform in England, Cambridge University Press, Cambridge.

Robinson, A. C., P. B. Copley, P. D. Canty, L. M. Baker and B. J. Nesbitt (eds), A Biological Survey of the Anangu Pitjatjantjara Lands of South Australia, 1991-2001, Department for Environment and Heritage, South Australia, Adelaide.

Rowley, C. D. 1970, The Destruction of Aboriginal Society, Penguin, Ringwood, Vic.

Rowse, Tim 1998, White Flour, White Power: From Rations to Citizenship in Central Australia, Cambridge University Press, Cambridge.

Santich, Barbara 2102, Bold Palates: Australia's Gastronomic Heritage, Wakefield Press, Adelaide.

Skinner, Rob and Alan Lester 2012, 'Humanitarianism and empire: New research agendas', The Journal of Imperial and Commonwealth History 40(5): 729-747.

Stanner, W. E. H. 1977, 'The history of indifference thus begins', Aboriginal History 1(1): 3-26.

Stylianou, Marianna 2009, "'A scandal which must be corrected": Reconsidering the success of the tuberculosis campaign', Health and History 11(2): 21-41. 
Thorne, Susan 1997, 'The conversion of Englishmen and the conversion of the world inseparable', in Tensions of Empire: Colonial Cultures in a Bourgeois World, Frederick Cooper and Ann L. Stoler (eds), University of California Press, Berkeley.

Trudinger, David 2004, 'Converting Salvation: Protestant Missionaries in Central Australia in the 1930s and 1940s', PhD thesis, The Australian National University.

Vernon, Michael 2007, Hunger: A Modern History, Harvard University Press, Cambridge, MA.

Walker, Robin 1986, 'Mr Lang's dole: The administration of food relief in New South Wales 1930-32', Labour History 51: 70-82.

Williams, John 2014, Open Door: A Personal Memoir of Dilys Williams, Australian eBook Publisher, Acacia Ridge, Qld.

Wise, Tigger 1985, The Self-made Anthropologist: A Life of A. P. Elkin, George Allen \& Unwin, Sydney.

Worboys, Michael 1988, 'The discovery of colonial malnutrition between the wars', in Imperial Medicine and Indigenous Societies, David Arnold (ed.), Manchester University Press, Manchester.

Young, Diana 2010, 'Dingo scalping and the frontier economy in the north-west of South Australia', in Indigenous Participation in Australian Economies, Ian Keen (ed.), ANU E Press, Canberra: 91-108. 
This text is taken from Aboriginal History, Volume 39, 2015, edited by Liz Conor, published 2015 by ANU Press,

The Australian National University, Canberra, Australia. 